\title{
Modifikasi Alat Penggulung Dinamo Sistem Manual Menjadi Otomatis Berbasis Arduino
}

\author{
Muhammad Syahwil ${ }^{1}$ \\ ${ }^{1}$ Politeknik Negeri Ujung Pandang, Makassar, Sulawesi Selatan. \\ Email:syahwil.alwi@gmail.com \\ Submisi: 23 November 2020; Penerimaan: 27 Desember 2020
}

\begin{abstract}
ABSTRAK
Penelitian ini bertujuan untuk merancang dan membuat alat penggulung dinamo yang bekerja secara otomatis dengan memodifikasi alat penggulung dinamo sistem manual yang ada di bengkel kampus. Alat ini menggantikan fungsi alat manual penggulung kawat email dinamo tenaga manusia menjadi alat otomatis dengan tenaga penggerak motor stepper sehingga proses penggulungan lilitan dinamo menjadi lebih efesien dan akurat. Metode penelitian yang dilakukan terdiri atas identifikasi potensi dan masalah, studi literature (pengumpulan data), tahap desain (perancangan, validasi rancangan dan pembuatan alat), tahap pengujian (uji coba), analisis unjuk kerja alat serta tahap finalisasi (uji coba pemakaian). Hasil akhir penelitian ini didapatkan sebuah alat penggulung dinamo yang beroperasi secara otomatis sebagaimana rancangan modifikasi yang diinginkan. Berdasarkan pengujian unjuk kerja di laboratorium, menunjukan alat penggulung otomatis ini berfungsi sangat baik dengan hasil pengamatan sebagai berikut: (1) Didapatkan kesesuaian hasil antara jumlah putaran aktual dan jumlah setting gulungan dengan tingkat ketelitian sebesar 99,38 \%, atau error selisih putaran sebesar 0,62 \%.; (2) Alat ini bekerja dengan 4 level kecepatan yaitu tinggi, cukup, sedang dan rendah dengan konsumsi daya listrik yang rendah sebesar 20 Watt. Dengan variasi kecepatan yang tersedia, pengguna dapat menggulung belitan sesuai dengan diameter kawat email yang digunakan; (3) Efektifitas penggulungan cukup baik, untuk menggulung kumparan dinamo sebanyak 500 lilitan hanya dibutuhkan waktu 3,15 menit (level kecepatan tinggi), 6,25 menit (level kecepatan cukup), 9,15 menit (level kecepatan sedang) dan 12,3 menit (level kecepatan rendah).
\end{abstract}

Kata Kunci: otomatis , modifikasi, alat penggulung dinamo, dan arduino.

\section{PENDAHULUAN}

Secara umum, pada industri skala kecil ataupun pada bengkel mesin-mesin listrik masih banyak dijumpai proses perbaikan gulungan trafo/dinamo menggunakan alat penggulung dinamo sistem manual dengan tenaga manusia. Hal ini disebabkan karena mesin penggulung otomatis memiliki harga yang cukup mahal. Penggunaan alat manual dalam proses penggulungan kawat email memakan waktu lama dengan tingkat ketelitian dan ketepatan hasil penghitungan jumlah lilitan kawat kurang akurat dan kecepatan putaran mesin tidak dapat diatur sesuai dengan kebutuhan. Kecepatan dan keakuratan hasil kerja sangat diperlukan dalam proses maintenance atau perawatan dan perbaikan mesin-mesin industri. Sebagai contoh, dalam proses perbaikan motor listrik, seringkali diperlukan penggantian kumparan motor. Hal ini memerlukan proses penggulugan kumparan motor listrik yang baru. Keakuratan jumlah lilitan motor menjadi salah satu hal yang 
penting dalam penggantian kumparan motor listrik ini.

Menurut Ahyar M \& Irdam (2019), pada penggulungan kumparan dengan mesin konvensional, proses penggulungan dilakukan secara manual dengan memutar handle sebanyak jumlah lilitan yang diinginkan. Kendala yang mungkin terjadi pada proses penggulungan manual ini antara lain adalah kecepatan kerja yang tidak konsisten, kontinuitas penggulungan yang tergantung pada operator, hasil pengulungan dapat tidak sesuai dengan yang diinginkan, dan memerlukan pengawasan selama proses penggulungan berlangsung. Mekanisme manual ini dapat dioptimalisasi dengan mengganti sistem kerja menjadi otomatis. Proses penggulungan dengan memutar handle bisa digantikan dengan motor listrik, pengontrolan kecepatan dan hasil penggulungan dapat dikendalikan melalui piranti pengendali seperti mikrokontroler. Proses dapat berlangsung secara otomatis sehingga ketergantungan pada operator untuk mengawasi secara penuh dapat dikurangi.

Tidak hanya pada industri skala kecil, pada bengkel Teknik Elektro Politeknik Negeri Ujung Pandang, saat ini mahasiswa masih menggunakan alat penggulung manual dalam kegiatan praktek bengkel perbaikan gulungan dinamo. Untuk mengoptimalkan kegiatan bengkel agar proses penggulungan kawat email menjadi efektif dan efesien dalam kegiatan bengkel mahasiswa, sangat penting untuk dilakukan penelitian ini yakni membuat Modifikasi Alat Penggulung Dinamo Sistem Manual Menjadi Otomatis Berbasis Arduino.

Alat yang dimodifikasi yaitu alat manual seperti yang ada di bengkel kampus, modifikasi dilakukan sedemikian rupa dengan menambahkan motor penggerak berupa motor stepper dan kontrol elektronik berbasis arduino sehingga alat penggulung dinamo hasil modifikasi berkerja secara otomatis dan kecepatan pengulungan kawat email dapat divariasikan. Dengan demikian, tujuan utama penelitian ini adalah merancang dan membuat alat penggulung dinamo yang bekerja secara otomatis dengan memodifikasi alat penggulung dinamo sistem manual yang sudah ada pada laboratorium/bengkel Teknik Elektro Politeknik Negeri Ujung Pandang. Ruang lingkup penelitian ini adalah mendesain/memodifikasi alat penggulung dinamo manual menjadi alat otomatis, membuat komponen mekanik dan sistem elektronik alat penggulung dinamo otomatis serta melakukan uji coba alat di laboratorium.

Kajian atau penelitian mengenai pembuatan mesin penggulung kumparan dinamo berbasis mikrokontroler telah banyak dilakukan. Gapita, Hamzah, dan Nurhalim (2015) telah merancang mesin penggulung transformator berbasis mikrokontroler ATMega8535. Mesin penggulung yang dibuat menggunakan motor AC dengan sensor magnet sebagai pendeteksi jumlah lilitan, mikrokontroler ATMega8535 sebagai pengendali utama, dan keypad serta LCD sebagai interface. Pengujian ketelitian mesin memberikan hasil kesalahan di bawah $5 \%$.

Yandri dan Desmiwarman (2016) juga telah membuat mesin penggulung kawat email untuk kumparan motor menggunakan mikrokontroler ATMega328 sebagai unit pengendali, mesin penggulung yang dihasilkan digerakkan dengan motor DC dengan pengaturan kecepatan menggunakan potensiometer, dan menggunakan limit switch sebagai penghitung jumlah putaran. Hasil penggulungan yang cepat dan akurat diperoleh pada setting PWM di bawah 210. 
Pada penelitian ini, dibuat mesin penggulung dinamo berbasis mikrokontroler arduino sebagai pengendali utama dengan melakukan modifikasi mesin penggulung manual yang ada dipasaran. Kelebihan dari mesin ini dibanding penelitian sebelumnya yaitu adanya pilihan variasi kecepatan yaitu tinggi, sedang, cukup dan rendah yang dapat dipilih via keypad sehingga kecepatannya dapat disesuaikan dengan diameter kawat email yang akan digunakan.

\section{METODE PENELITIAN}

\section{Tempat Penelitian}

Perancangan, modifikasi dan pembuatan alat dilaksanakan di bengkel Otomasi Industri, Jurusan Teknik Elektro, Politeknik Negeri Ujung Pandang.

\section{Alat dan Bahan}

Bahan dan alat yang digunakan dalam penelitian ini yaitu laptop dan software program interface compiler IDE (Integrated Development Environment ) arduino untuk mengupload kode bahasa pemrograman C ke mikrokontroler, Alat Gulung Dinamo Manual model jarum 1 buah, Board mikrokontroler arduino uno 1 buah, Shield board arduino 1 buah, LCD Display 4x20 karakter 1 buah, Keypad membran $4 \times 41$ buah, catu daya dc/adaptor $12 \mathrm{~V} 1$ buah, motor stepper 12 $V$ dc 1 buah, modul driver motor stepper 1 buah, saklar ON/OFF 1 buah, box elektronik, kabel jumper arduino 1 set, coupling shaft, bagian mekanik serta komponen pendukung lainnya.

\section{Cara kerja}

Metode penelitian yang digunakan dalam modifikasi alat ini adalah Reserach and Development (R\&D). Sugiyono (2010), mengungkapkan yang dimaksud dengan metode Penelitan dan pengembangan merupakan metode penelitian yang digunakan untuk menghasilkan produk tertentu dan menguji keefektifan produk tersebut. Sedangkan menurut Sudjadi (2003:164) penelitian dan pengembangan atau Reserach and Development (R\&D) adalah suatu proses atau langkahlangkah untuk mengembangkan suatu produk baru, atau menyempurnakan produk yang telah ada yang dapat dipertanggungjawabkan. Dalam penelitian ini mengunakan metode $R$ \& $D$ karena hasil akhir penelitian ini akan menghasilkan alat atau produk hasil modifikasi yaitu alat penggulung dinamo otomatis berbasis arduino. Langkahlangkah dalam penelitian dan pengembangan menurut Sugiyono dapat dilihat pada Gambar 1.

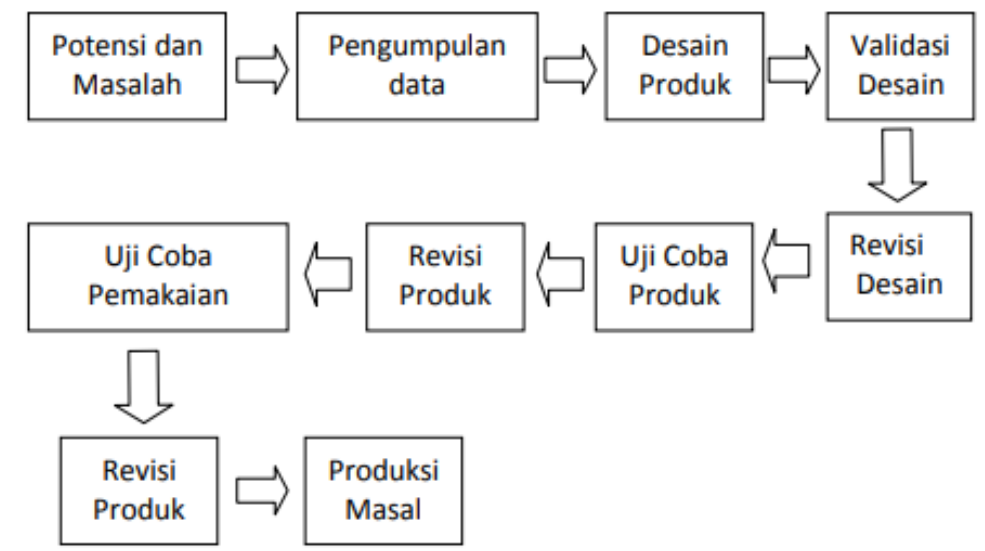

Gambar 1. Diagram prosedur penelitian R \& D (sumber gambar : Sugiyono, 2010) 
Dari 10 tahap yang dikembangakan oleh Sugiyono. hanya 7 tahap yang akan diadaptasikan dalam penelitian ini yaitu langkah 1 sampai dengan 7, yaitu : identifikasi potensi dan masalah, studi literature (pengumpulan data), tahap desain (perancangan, validasi rancangan dan pembuatan alat, tahap pengujian (uji coba), analisa unjuk kerja alat serta tahap finalisasi (uji coba pemakaian). Tahap perancangan meliputi disain rancangan modifikasi, membuat gambar layout, dan penyediaan material dan peralatan. Kemudian, tahap pembuatan meliputi pembuatan komponen mekanik, rangkaian listrik dan program mikrokontroler. Pada tahap pengujian yang dilakukan meliputi pengujian kecepatan penggulungan dan keakuratan penggulungan.

\section{Rancangan Modifikasi Alat}

1. Rancangan Mekanik

Alat manual yang dimodifikasi diperlihatkan seperti Gambar 1. Adapun rancangan atau rencana modifikasi alat dan penempatan/penambahan komponen mekanik dan elektrik diperlihatkan seperti skema gambar 2 .

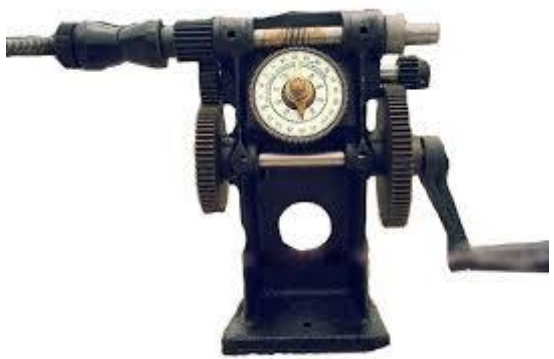

Gambar 2. Alat Manual Sebelum Dimodifikasi (sumber gambar: dokumentasi pribadi)

Adapun prinsip kerja alat modifikasi ini yaitu pertama, saklar power alat di on-kan, kemudian memasukkan input jumlah lilitan yang dinginkan via keypad. Misalnya jumlah lilitan yang dinginkan 200, angka inputan ini ditampilkan pada LCD displai, bila ada kesalahan input jumlah lilitan seperti anda salah menekan angka pada keypad misalnya 205 seharusnya 200 maka untuk menghapus input yang salah atau membenarkan angka yang salah tersebut yaitu dengan cara menekan huruf $\mathrm{C}$, kemudian memasukan kembali angka yang benar misal 200 tadi. Kecepatan motor stepper dapat diatur via tombol huruf $\mathrm{A}$ dan $\mathrm{B}$. Terdapat 4 pilihan kecepatan yaitu tinggi, sedang, cukup dan rendah. Pengaturan ini bisa disesuaikan dengan diameter kawat tembaga email yang akan digulung, kawat email yang halus biasanya membutuhkan kecepatan rendah untuk menghindari putusnya kawat saat proses penggulungan. Selanjutnya, menekan tombol START untuk memulai proses penggulungan kawat tembaga email. Saat alat ini beroperasi/motor stepper on, motor stepper akan tetap on sampai dipenuhi jumlah input lilitan, bila jumlah input yang dimasukkan via keypad sudah sesuai dengan data pulsa masukan motor stepper, maka otomatis proses penggulungan berhenti dan selesai. Proses pengulungan menjadi lebih cepat, efesien dan akurat.

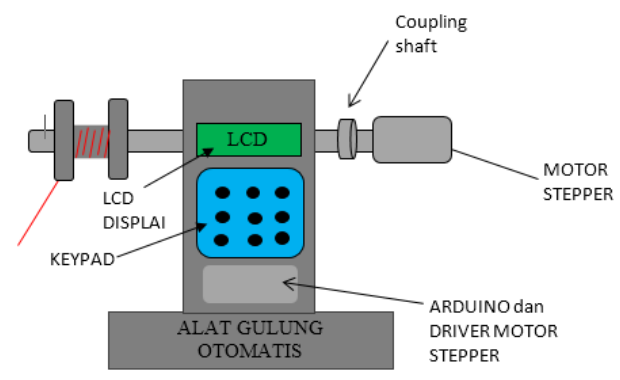

Gambar 3. Rancangan modifikasi alat penggulung otomatis (sumber gambar : dokumentasi pribadi)

2. Rancangan Elektronik

Pengontrolan atau rangkaian elektronik sistem alat penggulung dinamo otomatis yang dibuat berbasis 
mikrokontroller/Arduino yang terdiri dari 3 bagian:

1. Input. Bagian input adalah bagian yang berfungsi sebagai antarmuka antara manusia dengan sistem, bagian input ini direalisasikan dengan sebuah keypad, dimana pengguna dapat memasukkan perintah berupa nilai settingan jumlah gulungan, menentukan mode program yang aktif, serta perintah untuk memulai operasi, menambah dan mengurangi kecepatan motor stepper.

2. Proses. Bagian proses adalah bagian yang berfungsi sebagai pengolah data sekaligus mengendalikan jalannya kerja sistem. Pada bagian ini data dari bagian input diolah sedemikian rupa dan disimpan dalam memori sebagai program dari nilai kondisi output yang diinginkan, yang nantinya akan dijadikan sebagai nilai acuan/pembanding dari nilai yang telah dicapai aktuator. Adapun otak dari proses ini adalah sebuah Mikrokontroler Arduino. Arduino adalah kit elektronik atau papan rangkaian elektronik open source yang di dalamnya terdapat komponen utama yaitu sebuah chip mikrokontroler dengan jenis AVR dari perusahaan Atmel. Mikrokontroler itu sendiri adalah chip atau IC (integrated circuit) yang bisa diprogram menggunakan komputer (Syahwil, Muhammad, 2014). Tujuan menanamkan program pada mikrokontroler adalah agar rangkaian elektronik dapat membaca input, memproses input tersebut dan kemudian menghasilkan output sesuai yang diinginkan

3. Output. Pada bagian output teridiri 2 komponen yaitu motor stepper dan LCD displai. Motor stepper sebagai aktuator, dimana poros motor ini akan dihubungkan dengan sistem mekanik alat penggulung manual dan displai berfungsi untuk menampilkan data numerik baik nilai setting jumlah gulungan maupun nilai setting kecepatan putaran.

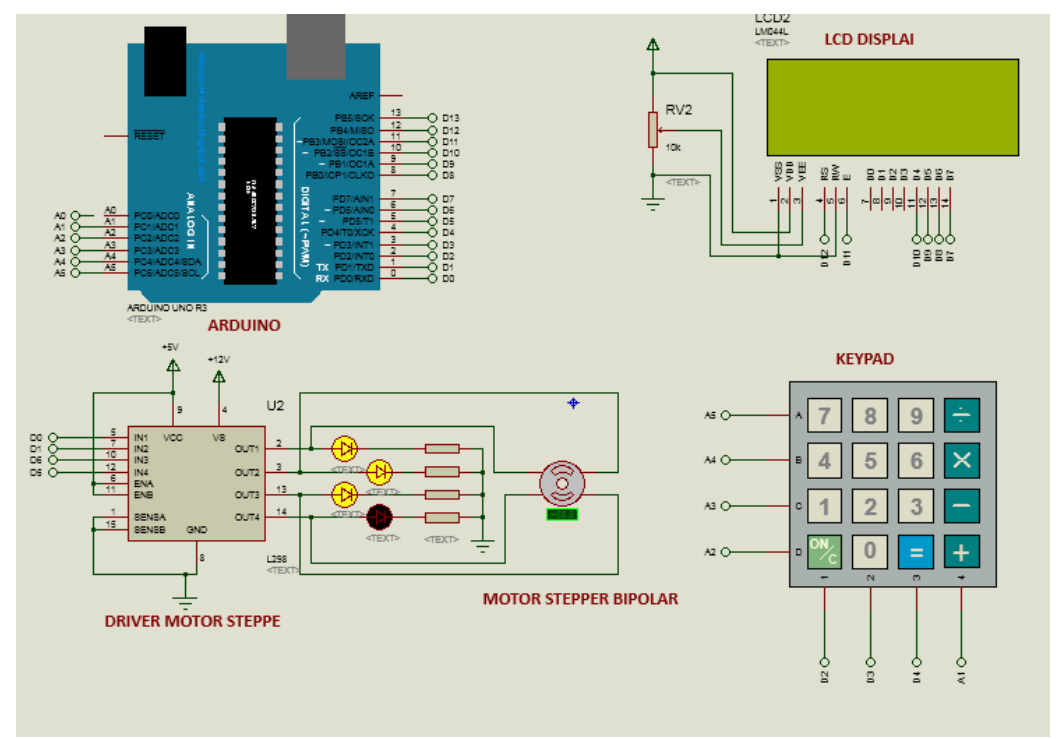

Gambar 4. Skematik Rangkaian elektronik

(sumber gambar: dokumentasi pribadi) 


\section{HASIL DAN PEMBAHASAN}

\section{Hasil Modifikasi Alat}

Penelitian ini telah menghasilkan alat mesin penggulung kumparan dinamo berbasis arduino. Bentuk fisik dari modifikasi alat yang telah dilakukan dalam penelitian ini seperti gambar 5 .

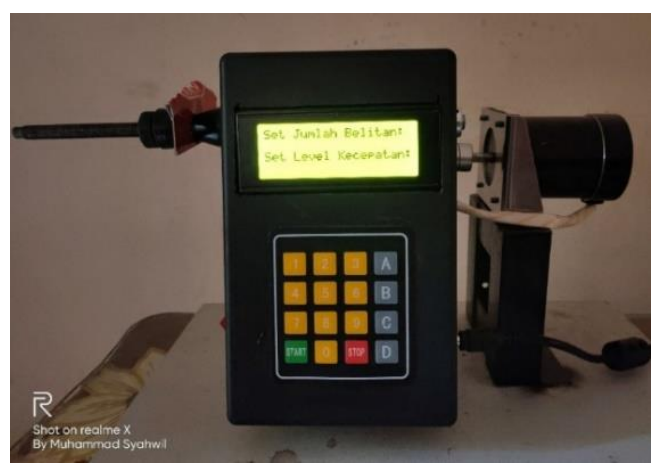

Gambar 5. Alat penggulung otomatis hasil modifikasi

(sumber gambar : dokumentasi pribadi)

Spesifikasi alat hasil modifikasi yaitu beroprasi menggunakan adapter tegangan listrik $12 \mathrm{~V}$, daya listrik $20 \mathrm{~W}$, memiliki 4 Level Kecepatan putaran yaitu Tinggi (160 rpm), Cukup (80 rpm), Sedang ( $55 \mathrm{rpm}$ ) dan rendah (40 rpm), mampu menghitung sampai 10.000 putaran, menggunakan LCD display 20x4 karakter dan pengoprasian alat menggunakan keypad matrix $4 \times 4$. Mekanisme kerja atau cara penggunaan alat ini sebagai berikut:

1. Mencolokan adapter (12V) pada sumber listrik 220V.

2. Memasukan ujung kawat email, pada mal penggulungan.

3. Menekan saklar power, setelah alat on, maka diperoleh tampilan pada LCD seperti gambar 5 .

4. Memasukkan input jumlah lilitan yang dinginkan via keypad misal 2 , yang ditampilkan pada LCD displai, bila ada kesalahan input jumlah lilitan misal anda menginput angka 5 padahal seharusnya angka 2, untuk menghapus input yang salah, caranya menekan tombol huruf $\mathrm{C}$.

5. Mengatur Set Level Kecepatan penggulungan dengan menekan tombol huruf $A$ dan atau B. Terdapat 4 level kecepatan yang bisa diatur yaitu Tinggi, Cukup, Sedang dan Rendah. Pengaturan ini bisa disesuaikan dengan diameter kawat tembaga email yang akan digulung, kawat email yang halus biasanya membutuhkan kecepatan rendah untuk menghindari putusnya kawat saat proses penggulungan.

6. Apabila Set Jumlah Belitan dan Set Level Kecepatan telah dipiilih. Selanjutnya menekan tombol START pada keypad untuk memulai proses penggulungan kawat tembaga email.

7. Proses penggulungan akan berhenti apabila telah mencapai jumlah lilitan yang dinginkan dan tampilan pada LCD displai tertulis SELESAI.

8. Menekan tombol $\mathrm{C}$ untuk kembali ke menu utama atau untuk penggulungan lainnya.

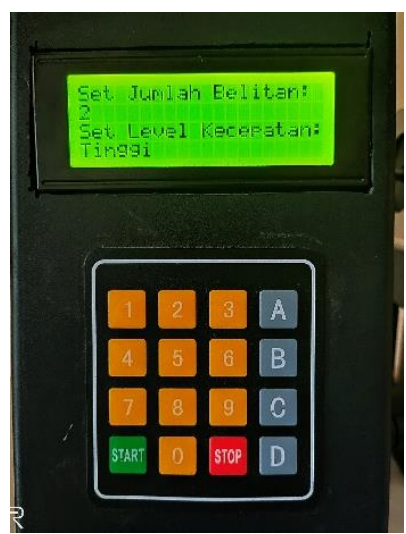

Gambar 6. Tampilan pada layar LCD (sumber gambar : dokumentasi pribadi)

\section{Pengujian Alat Hasil Modifikasi}

Untuk mengetahui tingkat ketelitian alat atau tingkat kesesuiaian pengukuran terhadap nilai sebenarnya 
maka dilakukan uji coba alat dengan membandingkan antara nilai setting jumlah putaran dengan nilai aktualnya. Pengukuran mesin gulung ini difokuskan pada ketelitian gulungan yang dihasilkan oleh putaran mesin gulung (nilai aktual) terhadap nilai setting putaran yang diinginkan. Nilai aktual diperoleh dengan menghitung jumlah putaran secara manual sesuai dengan input jumlah lilitan yang dinginkan sedangkan selisih putaran diketahui dengan memperhatikan posisi akhir kawat yang digulung yang diberi tanda saat awal penggulungan. Menurut Davic Cooper W, (1994), Ketelitian menyatakan tingkat kesesuaian atau dekatnya suatu hasil pengukuran terhadap harga sebenarnya.

Untuk mengetahui lama penggulungan pada setiap jumlah gulungan yang diinginkan dan setiap variasi level kecepatan yang dinginkan dari proses start penggulungan sampai mesin berhenti menggulung digunakan stopwatch. Hasil pengamatan dari pengukuran ini diperlihatkan pada tabel 1.

Tabel 1. Hasil pengukuran antara setting jumlah putaran dan putaran aktual serta lama waktu penggulungan

\begin{tabular}{lccc} 
No & \multicolumn{3}{c}{ Jumlah putaran } \\
& Setting & Aktual & Tinggi \\
1. & 1 & 1 & 0,01 \\
2. & 10 & 9,7 & 0,06 \\
3. & 50 & 49,6 & 0,32 \\
4. & 100 & 99,7 & 0,63 \\
5. & 200 & 199,5 & 1,26 \\
6. & 300 & 299,4 & 1,89 \\
7. & 400 & 399,6 & 2,52 \\
8. & 500 & 499,3 & 3,15
\end{tabular}

\begin{tabular}{ccc}
\multicolumn{2}{c}{ Level kecepatan } & \\
dan lama penggulungan (menit) & \\
Cukup & Sedang & Rendah \\
0,012 & 0,02 & 0,03 \\
0,12 & 0,18 & 0,25 \\
0,62 & 0,93 & 1,23 \\
1,25 & 1,83 & 2,46 \\
2,5 & 3,66 & 4,92 \\
3,75 & 5,5 & 7,38 \\
5 & 7,32 & 9,84 \\
6,25 & 9,15 & 12,3
\end{tabular}

Berdasarkan Tabel 1 diatas, untuk menggulung kumparan dinamo sebanyak 500 lilitan hanya dibutuhkan waktu sebanyak 3,15 menit pada level kecepatan tinggi, 6,25 menit pada level kecepatan cukup, 9,15 menit pada level kecepatan sedang dan 12,3 menit pada level kecepatan rendah. Untuk mengetahui besar kecepatan putaran motor stepper (RPM) tiap level kecepatan dapat dilakukan dengan cara membagi antara jumlah putaran dengan lama waktu putaran, demikian pula halnya tingkat ketelitian jumlah putaran dapat dihitung dengan membagi antara nilai aktual dengan nilai setting sebagaimana Persamaan 1. Sedangkan untuk mengetahui kecepatan putaran digunakan persamaan 2., Hasil perhitungan secara lengkap tersaji dalam Tabel 2 .

Presentase ketelitian (\%) $=$
$\quad \frac{\text { Jumlah putaran aktual }}{\text { Jumlah setting putaran }} \times 100 \%$
RPM $=$

$\frac{\text { Jumlah putaran aktual }}{\text { Lama waktu penggulungan dalam menit ... }}$

Berdasarkan nilai perhitungan tabel 2, menunjukan bahwa alat ini bekerja cukup baik dengan tingkat ketelitian sebesar 99,38\%, dan tingkat kesalahan atau error selisih putaran sebesar $0,62 \%$. Dimana didapatkan kesesuaian hasil antara jumlah gulungan dengan jumlah putaran motor stepper yang bekerja secara otomatis sehingga efesien menggantikan tenaga manusia dalam proses penggulungan belitan dinamo.

Berdasarkan Tabel 3, kecepatan rata-rata putaran motor untuk level kecepatan tinggi sebesar 151,09 rpm , level kecepatan Cukup sebesar 80,42 
rpm, level kecepatan Sedang sebesar 53,73 rpm dan level kecepatan rendah sebesar $40 \mathrm{rpm}$. Dengan pengaturan kecepatan yang tersedia, pengguna dapat menggulung belitan motor sesuai dengan diameter kawat email yang digunakan.

Tabel 2. Tingkat ketelitian jumlah putaran atau jumlabh gulungan

\begin{tabular}{cccc}
\hline No & Setting & Jumlah Putaran & $\begin{array}{c}\text { Tingkat } \\
\text { Ketelitian (\%) }\end{array}$ \\
\hline 1. & 1 & Aktual & 100 \\
2. & 10 & 9,7 & 97 \\
3. & 50 & 49,6 & 99,2 \\
4. & 100 & 99,7 & 99,7 \\
5. & 200 & 199,5 & 99,7 \\
6. & 300 & 299,4 & 99,8 \\
7. & 400 & 399,6 & 99,8 \\
8. & 500 & 499,3 & 99,8 \\
& & & 99,3 \\
\hline
\end{tabular}

Tabel 3. Kecepatan RPM mesin tiap level pengaturan kecepatan

\begin{tabular}{ccccc}
\hline \multirow{2}{*}{ No } & Tinggi & \multicolumn{2}{c}{ RPM Tiap Level Kecepatan } & Sedang \\
& 100,00 & 83,33 & 50,00 & Rendah \\
\hline 1. & 161,67 & 80,83 & 53,89 & 33,33 \\
2. & 155,00 & 80,00 & 53,33 & 38,80 \\
3. & 158,25 & 79,76 & 54,48 & 40,33 \\
4. & 158,33 & 79,80 & 54,51 & 40,53 \\
5. & 158,41 & 79,84 & 54,44 & 40,55 \\
6. & 158,57 & 79,92 & 54,59 & 40,57 \\
7. & 158,51 & 79,89 & 54,57 & 40,61 \\
8. & 151,09 & 80,42 & 53,73 & 39,41 \\
Rerata & & & & \\
\hline
\end{tabular}

\section{PENUTUP}

\section{Kesimpulan}

Hasil akhir penelitian ini didapatkan sebuah alat penggulung dinamo yang beroperasi secara otomatis sebagaimana rancangan modifikasi yang diinginkan. Berdasarkan pengujian unjuk kerja di laboratorium, menunjukan alat penggulung otomatis ini berfungsi sangat baik dengan hasil pengamatan sebagai berikut: (1) Didapatkan kesesuaian hasil antara jumlah putaran aktual dan jumlah setting gulungan dengan tingkat ketelitian sebesar 99,38\%, atau error selisih putaran sebesar 0,62 \%.; (2) Alat ini bekerja dengan 4 level kecepatan yaitu Tinggi, Cukup, Sedang dan rendah dengan konsumsi daya listrik yang rendah sebesar 20 Watt. Dengan variasi kecepatan yang tersedia, pengguna dapat menggulung belitan sesuai dengan diameter kawat email yang digunakan; (3) Efektifitas penggulungan cukup baik, untuk menggulung kumparan dinamo sebanyak 500 lilitan hanya dibutuhkan waktu 3,15 menit (level kecepatan tinggi), 6,25 menit (level kecepatan cukup), 9,15 menit (level kecepatan sedang) dan 12,3 menit (level kecepatan rendah).

\section{Saran}

Apabila alat ini ingin diproduksi untuk dijual, sebaiknya dilakukan desain baru komponen meknik yang lebih baik, tanpa menggunakan atau memodifikasi alat manual yang ada. Untuk meningkatkan kemampuan kecepatan putaran motor sebaiknya tidak menggunakan motor stepper, yang mana motor stepper dikenal sebagai motor dc 
yang beroperasi dengan kecepatan rendah namun memiliki torsi yang tinggi. Bisa menggunakan motor universal atau motor ac.

\section{DAFTAR PUSTAKA}

Ahyar M \& Irdam (2019). Perancangan Mesin Penggulung kumparan Motor Listrik Sistem Otomatis Berbasis Mikrokontroller. Jurnal Keteknikan dan Sains (JUTEKS) LPPM UNHAS Vol. 2, No. 1, Februari 2019.

Davic Cooper W, (1994), Instrumentasi Elektronik dan Teknik Pengukuran, edisi ke 2. Jakarta: Erlangga

Gapita, R. S., Hamzah, A., \& Nurhalim. (2015). Perancangan Mesin Penggulung Kumparan Transformator Berbasis Mikrokontroler ATmega8535. JOM FTEKNIK UNRI, 2(2), 1-5.

Sugiyono, (2010). Metode Penelitian Kuantitatif, Kualitatif dan $R \& D$. Penerbit CV alfabeta Bandung.

Sujadi, (2003). Metode Penelitian Pendidikan. Penerbit Jakarta Rineka Cipta.

Syahwil, Muhammad, (2014). Panduan Mudah Simulasi dan Praktek Mikrokontroler Arduino. Penerbit ANDI Yogyakarta.

Yandri, V. R., \& Desmiwarman. (2016). Rancang Bangun Alat Penggulung Kawat Email untuk Kumparan Motor Menggunakan Mikrokontroller ATmega328 Sebagai Unit Pengendali. Jurnal Teknik Elektro ITP, 5(1), 16-21. 